\title{
Hydrogeochemical processes controlling water and dissolved gas chemistry at the Accesa sinkhole (southern Tuscany, central Italy)
}

\author{
Franco TASSI, ${ }^{1,2^{*}}$ Gabriele BICOCCHI,${ }^{1}$ Jacopo CABASSI, ${ }^{1}$ Francesco CAPECCHIACCI,${ }^{1,2}$ Orlando VASELLI, ${ }^{1,2}$ \\ Enrico CAPEZZUOLI, ${ }^{3}$ Andrea BROGI ${ }^{4}$

\begin{abstract}
${ }^{1}$ Department of Earth Sciences, Via G. La Pira 4, 50121 Florence; ${ }^{2}$ CNR - Institute of Geosciences and Earth Resources, Via G. La Pira 4, 50121 Florence; ${ }^{3}$ Department of Physical Sciences, Earth and Environment, Via Laterina 8, 53100 Siena; ${ }^{4}$ Department of Earth and Geoenvironmental Sciences, Via Orabona 4, 70125 Bari, Italy
\end{abstract} \\ *Corresponding author: franco.tassi@unifi.it
}

\begin{abstract}
The $38.5 \mathrm{~m}$ deep Lake Accesa is a sinkhole located in southern Tuscany (Italy) that shows a peculiar water composition, being characterized by relatively high total dissolved solids (TDS) values $\left(2 \mathrm{~g} \mathrm{~L}^{-1}\right)$ and a $\mathrm{Ca}(\mathrm{Mg})-\mathrm{SO}_{4}$ geochemical facies. The presence of significant amounts of extra-atmospheric gases $\left(\mathrm{CO}_{2}\right.$ and $\left.\mathrm{CH}_{4}\right)$, which increase their concentrations with depth, is also recognized. These chemical features, mimicking those commonly shown by volcanic lakes fed by hydrothermal-magmatic reservoirs, are consistent with those of mineral springs emerging in the study area whose chemistry is produced by the interaction of meteoric-derived waters with Mesozoic carbonates and Triassic evaporites. Although the lake has a pronounced thermocline, water chemistry does not show significant changes along the vertical profile. Lake water balance calculations demonstrate that Lake Accesa has $>90 \%$ of its water supply from sublacustrine springs whose subterranean pathways are controlled by the local structural assessment that likely determined the sinking event, the resulting funnel-shape being then filled by the Accesa waters. Such a huge water inflow from the lake bottom $\left(\sim 9 \cdot 10^{6} \mathrm{~m}^{3} \mathrm{yr}^{-1}\right)$ feeds the lake effluent (Bruna River) and promotes the formation of water currents, which are able to prevent the establishment of a vertical density gradient. Consequently, a continuous mixing along the whole vertical water column is established. Changes of the drainage system by the deep-originated waters in the nearby former mining district have strongly affected the outflow rates of the local mineral springs; thus, future intervention associated with the ongoing remediation activities should carefully be evaluated to preserve the peculiar chemical features of Lake Accesa.
\end{abstract}

Key words: Central Italy, lake chemistry, Lake Accesa, sinkholes, lake water balance, structural geology setting.

Received: February 2014. Accepted: May 2014.

\section{INTRODUCTION}

Karst sinkholes are a common feature in the Tyrrhenian side of central-southern Italy (Santo et al., 2011, and references therein). The occurrence of ground collapses, basically produced by internal erosion and deformation processes caused by subsurface karstification (Williams, 2003; Sauro, 2003; Waltham et al., 2005), is likely favored by seismic activity (Del Prete et al., 2010) and circulation of $\mathrm{CO}_{2}\left(\mathrm{H}_{2} \mathrm{~S}\right)$-rich fluids (Duchi et al., 1986; Billi et al., 2007; Frondini et al., 2008). An enhanced hydrothermal activity in this area was interpreted as related to a heat flow anomaly (Gianelli et al., 1997; Batini et al., 2003; Bellani et al., 2004) and extensional structures coeval with the emplacement of granitoids at depth in the Late Miocene, exposed or drilled during mining exploitation (Serri et al., 1993; Dini et al., 2005; Benvenuti et al., 1994). Hydrothermal fluid patterns are currently controlled by Early Pliocene-Present high angle normal to strike-slip faults giving rise to local tectonic depressions (Bertini et al., 1991; Carmignani et al., 1994; Jolivet et al., 1998; Rossetti et al., 2011; Brogi et al., 2005; Liotta et al., 2010).
Lake Accesa (4259’ N; $10^{\circ} 53^{\prime} \mathrm{E}$; $157 \mathrm{~m}$ asl) is a waterfilled sinkhole located $5 \mathrm{~km}$ from the town of Massa Marittima (southern Tuscany, central Italy) and $12 \mathrm{~km}$ west of the Tyrrhenian Sea coast, located at the southern border of Colline Metallifere mining district, which is marked by oredeposits and widespread hydrothermal mineralization (Serri et al., 1991) (Fig. 1a). Exploitation activity of metal deposits since pre-Roman Age ( 2500 yrs BP) is here testified by the presence of a necropolis and an Etruscan settlement (Lobell, 2002). In the past century, mineral exploitation mainly focused on the $\mathrm{Cu}-\mathrm{Pb}-\mathrm{Zn}-\mathrm{Ag}$ deposit of Fenice Capanne (Mascaro et al., 2001), and the pyrite deposits of Niccioleta and Gavorrano (Fig. 1b). In historic times, water from Lake Accesa was used to wash minerals from the Island of Elba and other regional and local mines (Rizzotto, 1981). The existence of the lake, which has an effluent (Bruna River) and no tributaries, seems to depend on the occurrence of mineral springs mainly discharging from the lake bottom, e.g. Paradiso spring, and partly by subaerial contribution, Inferno spring (Magny et al., 2007; Negri, 2008; Vannière et al., 2008). 
In this work, the chemical and isotopic compositions of water and dissolved gases of Lake Accesa are presented and discussed. The main goal is to investigate the role played by i) the external fluid source(s) and ii) biogeochemical processes, such as water-rock interactions and microbial activity, for determining the lake chemistry along the vertical profile.

\section{GEOSTRUCTURAL OUTLINES OF THE STUDY AREA}

Southern Tuscany is characterized by a thinned continental crust and lithosphere (Nicolich, 1989) that has favored the presence of a high heat flow, the most relevant expressions being represented by the Larderello-Travale and Mt. Amiata geothermal fields (Batini et al., 2003 and references therein) and a large number of gas $\left(\mathrm{CO}_{2}-\mathrm{H}_{2} \mathrm{~S}\right)$ rich thermo-mineral springs (Minissale, 2004; Minissale et al., 1997, and references therein). This tectonic setting results from the convergence and collision (CretaceousEarly Miocene) between the Adria Plate and the Sardinia-
Corsica Massif with the consequent stacking of the tectonic units and their subsequent compression (to the East) and extension (to the West) from the Early-Middle Miocene to Present (Elter et al., 1975; Carmignani et al., 1995, 2001, and references therein) and late-Apenninic magmatism (Tanelli, 1983; Lattanzi et al., 1994; Costagliola et al., 2008). Historically-exploited base metal-sulfur ore deposits and S-bearing mineralizations that form the mining district of Colline Metallifere, are hosted within sedimentary and Palaezoic (phyllites) and Triassic (dolostone and gypsum/anhydrite) rocks that are covered by Ligurian Units produced by an extensional detachment occurring in Middle-Late Miocene (Arisi Rota and Vighi, 1971; Tanelli, 1983).

In the study area large outcrops of Mesozoic limestone deposits occur and are able to host large volume of meteoric waters that interact with deep-originated $\mathrm{CO}_{2}-\mathrm{H}_{2} \mathrm{~S}$-rich fluids favoring the formation of sinkholes and dolines (Nisio et al., 2007; Caramanna et al., 2008; Liotta et al., 2010). The funnel-shaped Lake Accesa, originated by karstic collapse, is located at the intersec-

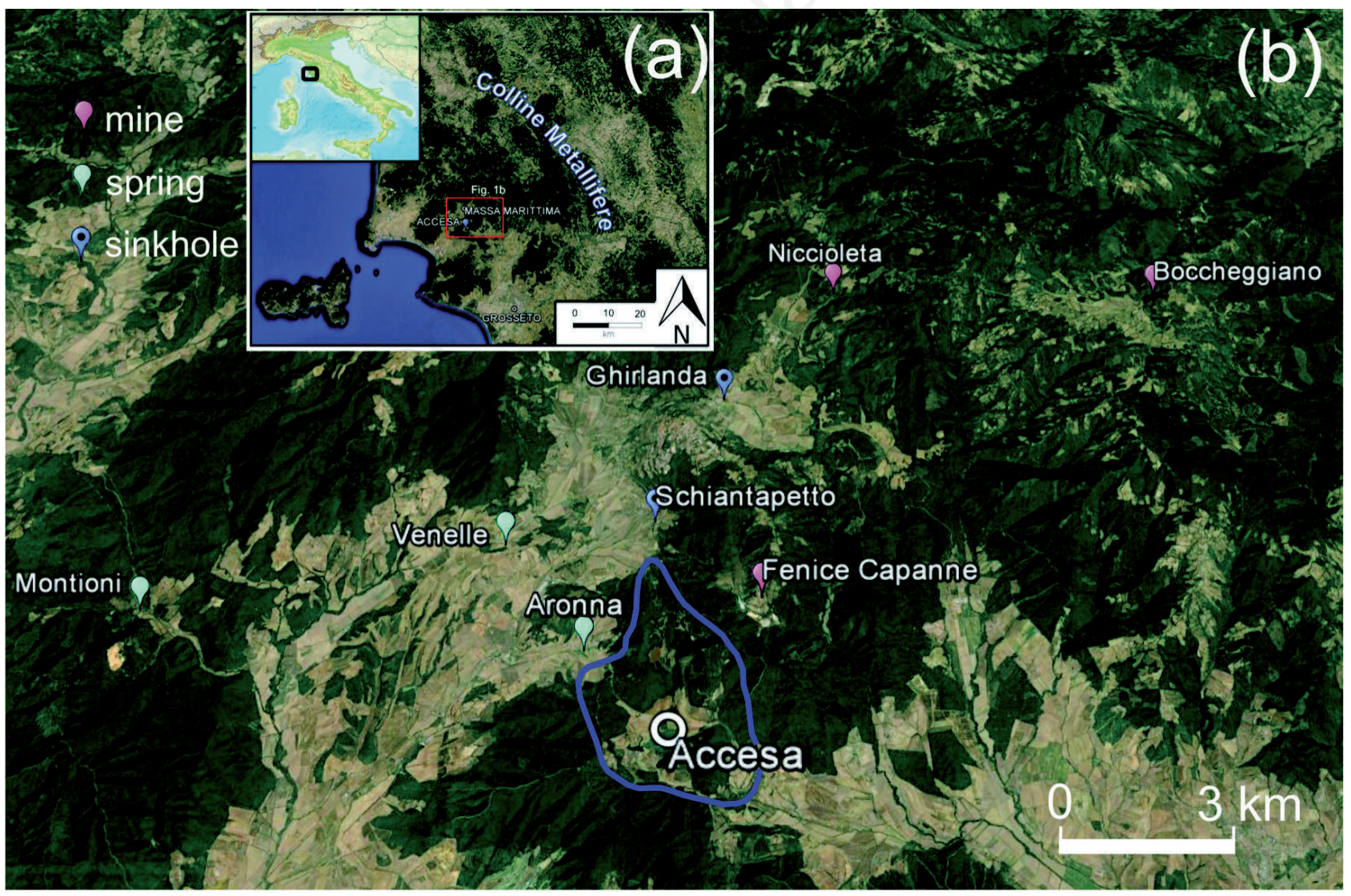

Fig. 1. Geographic map of the (a) southern Tuscany with the location of the Colline Metallifere mining district, and (b) the study area with the location of i) Lake Accesa and its catchment area, ii) Aronna Venelle and Montioni springs, iii) Ghirlanda and Schiantapetto sinkholes, iv) Niccioleta, Boccheggiano and Fenice Capanne mines (image Landsat (C2014 Google). 
tion of two NW- and NE-trending faults (Merciai, 1933; Magny et al., 2007; Negri et al., 2008; Vanniere et al., 2008) (Fig. 2), which allow the uprising of subaqueous springs feeding the lake (Negri, 2008). It is worthwhile to mention that the NW-trending fault system is also controlling spring waters (Aronna and Venelle; Bencini et al., 1977; Celati et al., 1990; Fig. 1b), located in correspondence of small karstic depressions north of Lake Accesa, and other sub-circular depressions (Ghirlanda and Schiantapetto, Caramanna et al., 2008) occurring nearby (Fig. 1b).

\section{SAMPLING AND ANALYTICAL METHODS}

Field measurements and water and dissolved gas sampling

In May 2012, water depth $(\mathrm{m})$, temperature $\left({ }^{\circ} \mathrm{C}\right), \mathrm{pH}$, dissolved $\mathrm{O}_{2}(\mu \mathrm{mol} / \mathrm{L})$, and electrical conductivity (EC in $\mathrm{S} \mathrm{cm}^{-1}$ ), corrected at room ambient temperature: $20^{\circ} \mathrm{C}$, were measured along the lake vertical profile using a Hydrolab multiparameter probe (Idroprobe) equipped with a data logger for data storage. The nominal precisions are: depth, $\pm 0.05 \mathrm{~m}$; temperature, $\pm 0.03{ }^{\circ} \mathrm{C} ; \mathrm{pH}, \pm 0.1 ; \mathrm{O}_{2}, \pm 2$ $\mu \mathrm{mol} / \mathrm{L} ; \mathrm{EC}, \pm 5 \mathrm{~S} \mathrm{~cm}^{-1}$.

On the same date, water and dissolved gas sampling was carried out from the lake surface to the bottom at intervals of $5 \mathrm{~m}$ at a site corresponding to the deepest point of the lake (42059'16" N, 10 $\left.0^{\circ} 53^{\prime} 44^{\prime \prime} \mathrm{E}\right)$. The sampling equipment consisted of a set of $10 \mathrm{~m}$ long Rilsan ${ }^{\circledR}$ tubes $(\phi=6 \mathrm{~mm})$ connected by steel connectors. Once the Rilsan ${ }^{\mathbb{R}}$ tube was lowered to the chosen depth, water was pumped up to the surface by means of a $150 \mathrm{~mL}$ glass syringe equipped with a three-way valve and transferred into plastic bottles after the displacement of a water volume double than the inner volume of the Rilsan tube (Tassi et al., 2009). One water sample from the Aronna $\left(43^{\circ} 00^{\prime} 18^{\prime \prime} \mathrm{N}\right.$, $\left.10^{\circ} 52^{\prime} 36^{\prime \prime} \mathrm{E}\right)$ mineral spring located near the lake (Fig. 1) was also collected.

Filtered aliquots of water were transferred in $125 \mathrm{~mL}$ polyethylene bottles for the analysis of anions, cations (acidified with $\mathrm{HCl} \mathrm{30 \%} \mathrm{wt)} \mathrm{and} \mathrm{trace} \mathrm{species} \mathrm{(acidified}$ with ultrapure $\mathrm{HNO}_{3} 65 \% \mathrm{wt}$ ). An aliquot $(8 \mathrm{~mL}$ ) of water was collected in plastic tubes filled with $2 \mathrm{~mL}$ of a Cd$\mathrm{NH}_{4}$ solution for the determination of the reduced sulfur

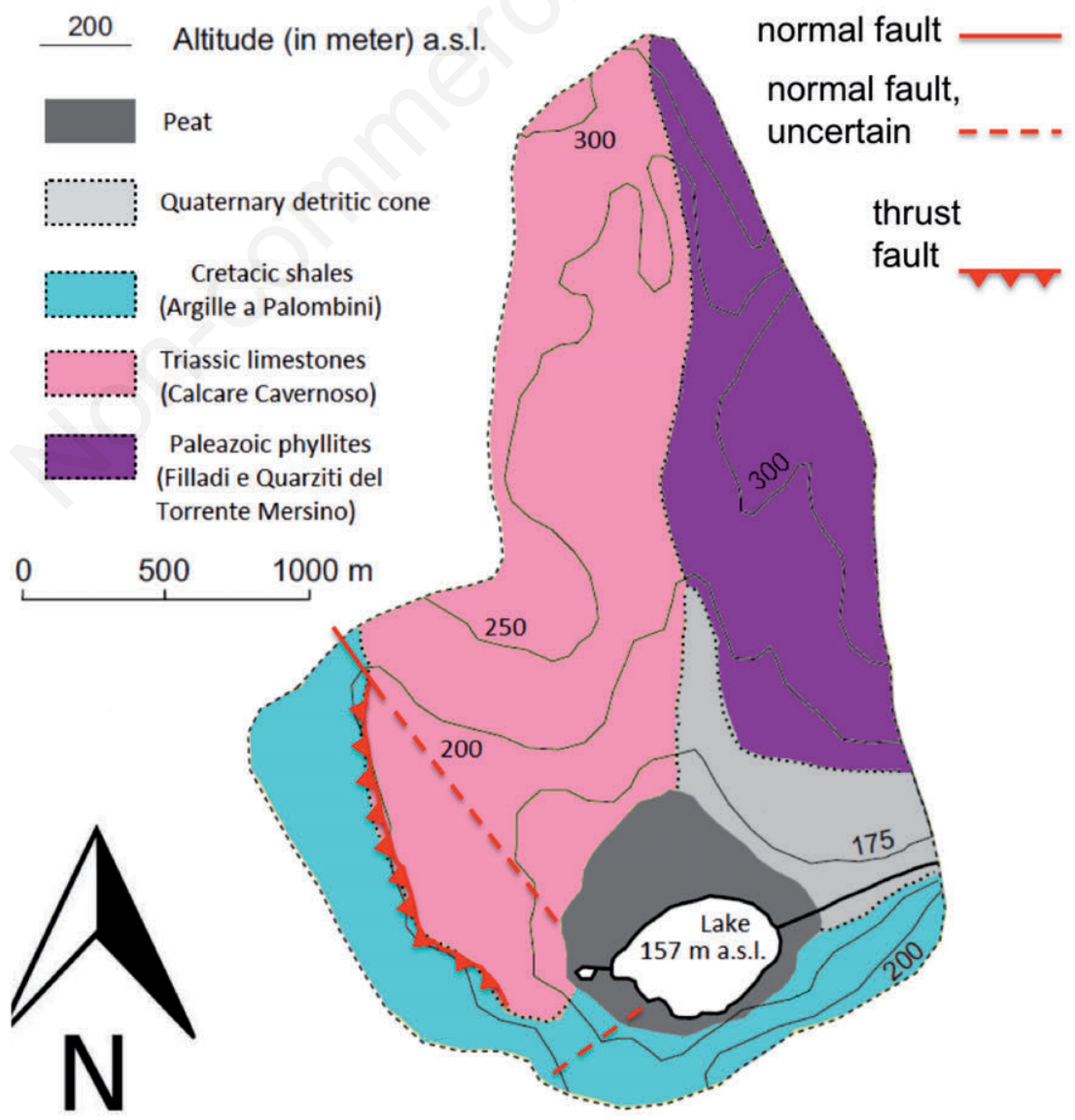

Fig. 2. Schematic geostructural map of Lake Accesa catchment area (modified after Magny et al., 2007). 
species $\left(\mathrm{H}_{2} \mathrm{~S}, \mathrm{HS}^{-}\right.$and $\mathrm{S}^{2-}$, expressed as $\left.\Sigma \mathrm{S}^{2-}\right)$ according to Montegrossi et al. (2006). Water samples collected in $500 \mathrm{~mL}$ polyethylene bottles with the addition of $\mathrm{HgCl}_{2}$ were used for the analysis of $\delta^{2} \mathrm{H}, \delta^{18} \mathrm{O}, \delta^{34} \mathrm{~S}-\mathrm{SO}_{4}$ and $\delta^{13} \mathrm{C}$ of total dissolved inorganic carbon (TDIC). Dissolved gases were sampled using pre-evacuated $250 \mathrm{~mL}$ glass vials equipped with a Teflon stopcock that were connected to the Rilsan tube and filled with water up to about three fourths of their inner volume (Chiodini, 1996; Tassi et al., 2008). Flow rate measurements of the Bruna River emissary were carried out at La Pesta site, about $600 \mathrm{~m}$ downstream of Lake Accesa, using a mechanical current-meter method. Stream section and velocity were measured using a steel tape and a current meter, respectively.

\section{Chemical and isotopic analysis of waters}

Total alkalinity $\left(\mathrm{HCO}_{3}{ }^{-}\right.$in Tab. 1$)$ was analyzed via acidimetric titration with $0.01 \mathrm{~N} \mathrm{HCl}$ using a Metrohm 794 automatic titration unit. Major cations $\left(\mathrm{Ca}^{2+}, \mathrm{Mg}^{2+}\right.$, $\mathrm{Na}^{+}, \mathrm{K}^{+}$and $\left.\mathrm{NH}_{4}^{+}\right)$and anions $\left(\mathrm{Cl}^{-}, \mathrm{SO}_{4}{ }^{2-}, \mathrm{NO}_{3}^{-}, \mathrm{Br}^{-}\right.$and $\mathrm{F}^{-}$) were analyzed by ion chromatography (Metrohm 861 and $761 \mathrm{IC}$, respectively). Reduced sulfur species $\left(\Sigma \mathrm{S}^{2-}\right)$ were analyzed as $\mathrm{SO}_{4}{ }^{2-}$ by ion chromatography (Metrohm 761 IC), as described in Montegrossi et al. (2006). Selected minor and trace elements $\left(\mathrm{Al}^{3+}, \mathrm{As}, \mathrm{B}, \mathrm{Fe}_{\text {tot }}, \mathrm{Li}^{+}\right.$, $\mathrm{Mn}^{2+}, \mathrm{Rb}^{+}, \mathrm{Sr}^{2+}$ and $\mathrm{Zn}^{2+}$ ) were analyzed at the CSA Laboratory (Rimini, Italy) by ICP-MS on the samples acidified with $1 \%$ ultra-pure $\mathrm{HNO}_{3}$. Analytical errors for chemical analysis of major, minor and trace compounds were $<5 \%$. Water isotopes (expressed as $\delta^{18} \mathrm{O}$ and $\delta^{2} \mathrm{H} \%$ $v s$ V-SMOW) in water samples were analyzed using a Finnigan Delta Plus XL mass spectrometer according to standard protocols. Oxygen isotopes were analyzed using the $\mathrm{CO}_{2}-\mathrm{H}_{2} \mathrm{O}$ equilibration method proposed by Epstein and Mayeda (1953). Hydrogen isotopes were analyzed on $\mathrm{H}_{2}$ produced after the reaction of $10 \mathrm{~mL}$ of water with metallic zinc at $500{ }^{\circ} \mathrm{C}$ (Coleman et al., 1982). Analytical errors for $\delta^{18} \mathrm{O}$ and $\delta^{2} \mathrm{H}$ analysis were $\pm 0.1 \%$ and $\pm 1 \%$, respectively. The ${ }^{3} \mathrm{H}$ content (TU, tritium unit; $1 \mathrm{TU}=119$ $\mathrm{Bq} \mathrm{m}^{-3}$ ) in one selected sample (Lake Accesa, $15 \mathrm{~m}$ depth) was determined at the Geoisotopical Unit of Public Health, Department of Chemistry (Koper, Slovenia) using Liquid Scintillation Counting (LSC) technique. For the analysis, $500 \mathrm{~mL}$ of sample were transferred to a pyrex container with carborundum ( $\mathrm{SiC}$ ), adding $250 \mathrm{mg}$ of $\mathrm{Na}_{2} \mathrm{~S}_{2} \mathrm{O}_{3}$ and $500 \mathrm{mg}$ of $\mathrm{Na}_{2} \mathrm{CO}_{3}$. Blank and samples were prepared by mean of a distillation apparatus. The analytical error was $1 \mathrm{~Bq} \mathrm{~m}^{-3}$ on $100 \mathrm{~Bq} \mathrm{~m}^{-3}(1 \%)$. The ${ }^{13} \mathrm{C} /{ }^{12} \mathrm{C}$ ratios of total dissolved inorganic carbon (TDIC; expressed as $\delta^{13} \mathrm{C}$-TDIC \%o vs V-PDB) were determined on $\mathrm{CO}_{2}$ produced by reaction of $3 \mathrm{~mL}$ of water with $2 \mathrm{~mL}$ of anhydrous phosphoric acid in vacuum (Salata et al., 2000) using a Finnigan Delta Plus XL mass spectrometer. The recovered $\mathrm{CO}_{2}$ was analyzed using a Finningan Delta $\mathrm{S}$




mass spectrometer after two-step extraction and purification procedures of the gas mixtures by using liquid $\mathrm{N}_{2}$ and a solid-liquid mixture of liquid $\mathrm{N}_{2}$ and trichloroethylene (Evans et al., 1998; Vaselli et al., 2006). Internal (Carrara and San Vincenzo marbles) and International (NBS18 and NBS19) standards were used for estimating the external precision. The analytical error and the reproducibility were $\pm 0.05 \%$ and $\pm 0.1 \%$, respectively.

The analysis of ${ }^{34} \mathrm{~S} /{ }^{32} \mathrm{~S}$ ratios of $\mathrm{SO}_{4}{ }^{2-}\left(\delta^{34} \mathrm{~S}_{-} \mathrm{SO}_{4}\right.$ expressed as \%o vs V-CDT) was carried out at Iso-Analytical laboratory in UK. Prior to the analysis an appropriate amount of sample was used to precipitate barium sulfate by the addition of a $10 \%(\mathrm{w} / \mathrm{v})$ barium chloride solution. The resulting precipitate was collected via centrifugation and dried. Using an automatic sampler, reference or sample material plus vanadium pentoxide catalyst were dropped into a furnace held at $1080{ }^{\circ} \mathrm{C}$ and then combusted at $\sim 1700^{\circ} \mathrm{C}$ in the presence of oxygen. Combusted gases were then swept in a helium stream over combustion catalysts (tungstic oxide/zirconium oxide) and through a reduction stage of high purity copper wires to produce $\mathrm{SO}_{2}, \mathrm{~N}_{2}, \mathrm{CO}_{2}$, and water. Water was removed using a Nafion ${ }^{\mathrm{TM}}$ membrane. Sulfur dioxide was resolved from $\mathrm{N}_{2}$ and $\mathrm{CO}_{2}$ on a packed $\mathrm{GC}$ column at $45^{\circ} \mathrm{C}$. The resultant $\mathrm{SO}_{2}$ peak entered the ion source of the IRMS (Isotope-Ratio Mass Spectrometer) where it was ionized and accelerated. Gas species of different mass were separated in a magnetic field and measured on a Faraday cup universal collector array. Analysis was based on monitoring of $\mathrm{m} / \mathrm{z} 48,49$ and 50 of $\mathrm{SO}^{+}$produced from $\mathrm{SO}_{2}$ in the ion source. The reference material used for analysis was IA-R061 (Iso-Analytical working standard barium sulfate, $\delta^{34} \mathrm{~S}=+20.33 \%$ vs $\mathrm{V}$-CDT). IA-R025 (Iso-Analytical working standard barium sulfate, $\delta^{34} \mathrm{~S}=+8.53 \%$ vs VCDT), IA-R026 (Iso-Analytical working standard silver sulfide, $\delta^{34} \mathrm{~S}=+3.96 \%$ vs V-CDT) and IA-R061 were used for calibration and correction of the ${ }^{18} \mathrm{O}$ contribution to the $\mathrm{SO}+$ ion beam. Working standards were traceable to NBS-127 (barium sulfate, $\delta^{34} \mathrm{~S}=+20.3 \%$ vs V-CDT), IAEA-SO-5 (barium sulfate, $\delta^{34} \mathrm{~S}=+0.5 \%$ vs $\mathrm{V}$-CDT) and IAEA-S-1 (silver sulfide, $\delta^{34} \mathrm{~S}=-0.3 \% v v$ V-CDT).

\section{Chemical and isotopic analysis of dissolved gases}

The composition of the inorganic gas compounds $\left(\mathrm{CO}_{2}, \mathrm{~N}_{2}, \mathrm{Ne}, \mathrm{O}_{2}\right.$ and $\left.\mathrm{Ar}\right)$ stored in the headspace of the sampling flasks was determined using a Shimadzu 15A gas chromatograph (GC) equipped with a $5 \mathrm{~m}$ long stainless steel column packed with Porapak 80/100 mesh and a Thermal Conductivity Detector (TCD), whereas $\mathrm{CH}_{4}$ was analyzed using a Shimadzu 14A GC equipped with a $10 \mathrm{~m}$ long stainless steel column packed with Chromosorb PAW 80/100 mesh coated with 23\% SP 1700 and a Flame Ionization Detector (FID) (Vaselli et al., 2006; Tassi et al., 2008). The analytical error for GC analysis was $\leq 5 \%$.
The ${ }^{13} \mathrm{C} /{ }^{12} \mathrm{C}$ ratios of $\mathrm{CO}_{2}$ in the headspace of the sampling flasks $\left(\delta^{13} \mathrm{C}_{-} \mathrm{CO}_{2}\right.$ expressed as \%o vs V-PDB) were analyzed using the same instrument and purification procedure used for the determination of the $\delta^{13} \mathrm{C}$-TDIC values. The ${ }^{13} \mathrm{C} /{ }^{12} \mathrm{C}$ ratios of dissolved $\mathrm{CO}_{2}\left(\delta^{13} \mathrm{C}-\mathrm{CO}_{2 \mathrm{aq}}\right)$ were recalculated on the basis of $\delta^{13} \mathrm{C}_{-} \mathrm{CO}_{2}$ values, considering the isotopic fractionation caused by gas release from water occurred during the sampling procedure was quantified by using the $\varepsilon_{1}$ fractionation factor for the gas-water equilibrium (Zhang et al., 1995), as follows:

$\varepsilon_{1}=\delta^{13} \mathrm{C}-\mathrm{CO}_{2 \mathrm{aq}}-\delta^{13} \mathrm{C}-\mathrm{CO}_{2}=(0.0049 \cdot \mathrm{T})-1.31$

where temperature (T) is expressed in ${ }^{\circ} \mathrm{C}$.

The analysis of $\delta^{13} \mathrm{C}$ in $\mathrm{CH}_{4}\left(\delta^{13} \mathrm{C}^{-} \mathrm{CH}_{4}\right.$ expressed as \%o vs V-PDB) was carried out by mass spectrometry (Varian MAT 250) according to the procedure described by Schoell (1980). The analytical error was $\pm 0.15 \%$.

\section{RESULTS}

\section{Lake morphology}

Up to 500 bathymetric data, measured with a GPSMAP $^{\circledR}$ 526s (Garmin, Olathe, KS, USA) ecosounder, were used to reconstruct the lake morphology (Fig. 3). The lake has a sub-circular shape, a diameter of $\sim 400 \mathrm{~m}$, a maximum depth of $38.5 \mathrm{~m}$, a surface area of $16 \times 10^{4} \mathrm{~m}^{2}$ and a volume of $2.39 \times 10^{6} \mathrm{~m}^{3}$. The catchment area (Fig. 2), delimited by small hills culminating at 350 $\mathrm{m}$ asl, covers $5 \mathrm{~km}^{2}$. In this area, the outcropping geological formations include: Paleazoic phyllites, Triassic limestones, Cretacic shales and Quaternary debris. The Lake Accesa lies on peat deposits (Fig. 2). In 1912, the lake level was artificially lowered to extend arable lands. This intervention significantly diminished the submerged littoral platform that currently account for a $5-20 \mathrm{~m}$ wide carbonate bench. Below this zone, the lake profile shows a steep slope, followed by a gentle slope that reaches the sub-horizontal bottom of the lake (Fig. 3).

\section{Vertical profiles of temperature, $\mathrm{EC}, \mathrm{pH}$ and dissolved $\mathrm{O}_{2}$}

Temperature, EC, $\mathrm{pH}$, and dissolved $\mathrm{O}_{2}$ concentrations measured along the vertical profiles of Lake Accesa are shown in Fig. 4 a-d. The lake had a thermocline at 10-15 $\mathrm{m}$ depth, where temperature decreased from 20 to $9{ }^{\circ} \mathrm{C}$ and then remained relatively constant down to the bottom (Fig. 4a). EC values did not significantly change with depth, showing a slight increase from 1.93 to $1.98 \mathrm{mS} \mathrm{cm}^{-1}$ (Fig. $4 \mathrm{~b}$ ). In the very first $3 \mathrm{~m}$, the $\mathrm{pH}$ values abruptly decreased from 7.9 to 7.7 , then progressively increased, reaching 8.1 at $25 \mathrm{~m}$ depth, whereas they slight decreased to 8.0 toward the bottom (Fig. 4c). Dissolved $\mathrm{O}_{2}$ concentrations strongly increased, from 250 to $380 \mu \mathrm{mol} \mathrm{L}^{-1}$, at $\sim 10 \mathrm{~m}$ depth, in 
correspondence of the thermocline. Thus, the $\mathrm{O}_{2}$ increasing trend is to be interpreted as related to an increase of $\mathrm{O}_{2}$ solubility at decreasing temperatures. Below this depth $\mathrm{O}_{2}$ concentrations decreased reaching the minimum vales of $215 \mu \mathrm{mol} \mathrm{L}^{-1}$ at the lake bottom (Fig. 4d).

\section{Chemical and isotopic $\left(\delta^{18} \mathrm{O}, \delta^{2} \mathrm{H}, 3 \mathrm{H}, \delta^{13} \mathrm{C}\right.$-TDIC and $\delta^{34} \mathrm{~S}^{-\mathrm{SO}_{4}}$ ) composition of lake water}

The lake is characterized by a relatively high total dissolved solids (TDS) (up to $2336 \mathrm{mg} \mathrm{L}^{-1}$ at the bottom) and a $\mathrm{Ca}-\mathrm{SO}_{4}$ composition $\left(\mathrm{Ca}\right.$ and $\mathrm{SO}_{4}$ concentrations were up to 470 and $1290 \mathrm{mg} \mathrm{L}^{-1}$, respectively) (Tab. 1). $\mathrm{Mg}^{2+}, \Sigma \mathrm{S}^{2-}$ and $\mathrm{HCO}_{3}{ }^{-}$concentrations were relatively high (up to 105,161 and $280 \mathrm{mg} \mathrm{L}^{-1}$ ), whereas minor concentrations of $\mathrm{Cl}^{-}\left(<43 \mathrm{mg} \mathrm{L}^{-1}\right), \mathrm{Na}^{+}\left(<14 \mathrm{mg} \mathrm{L}^{-1}\right)$, $\mathrm{K}^{+}\left(<4.6 \mathrm{mg} \mathrm{L}^{-1}\right), \mathrm{Sr}^{2+}$ (up to $\left.7.2 \mathrm{mg} \mathrm{L}^{-1}\right), \mathrm{NO}_{3}^{-}(<3.4 \mathrm{mg}$ $\mathrm{L}^{-1}$ ), $\mathrm{B}$ (up to $1.6 \mathrm{mg} \mathrm{L}^{-1}$ ), $\mathrm{F}^{-}$(up to $2.5 \mathrm{mg} \mathrm{L}^{-1}$ ) and $\mathrm{NH}_{4}^{+}$ $\left(<0.23 \mathrm{mg} \mathrm{L}^{-1}\right)$ were measured. Concentrations of other trace elements $\left(\mathrm{Al}^{3+}, \mathrm{As}, \mathrm{Br}^{-}, \mathrm{Fe}_{\text {tot }}, \mathrm{Li}^{+}, \mathrm{Mn}^{2+}, \mathrm{Rb}^{+}\right.$, and $\mathrm{Zn}^{2+}$ ) were $<0.1 \mathrm{mg} \mathrm{L}^{-1}$ (Tab. 1). In agreement with the relatively constant $\mathrm{EC}$ values along the vertical profile (Fig. 4b), all the analyzed ion species did not show any significant variation (Tab. 1).
The $\delta^{18} \mathrm{O}-\mathrm{H}_{2} \mathrm{O}$ and $\delta^{2} \mathrm{H}-\mathrm{H}_{2} \mathrm{O}$ values (Tab. 2) varied in a narrow range, from -5.94 to $-5.72 \%$ os $\mathrm{V}-\mathrm{SMOW}$ and from -42.4 to $-37.8 \%$ vs V-SMOW, respectively. The $\delta^{13} \mathrm{C}$-TDIC values ranged from -2.5 to $0.33 \%$ vs V-PDB. No clear trends with depth were shown by these isotopic parameters. The ${ }^{3} \mathrm{H}$ value was $3 \mathrm{TU}$ (Tritium Unit). The $\delta^{34} \mathrm{~S}$ values, measured in water samples collected from the lake surface and at the depths of 15 and $35 \mathrm{~m}$, slightly increased with depth, from 13.70 to $14.12 \%$ vs V-CDT.

\section{Chemical and isotopic ( $\delta 13 \mathrm{C}-\mathrm{CO} 2 \mathrm{aq})$ composition of dissolved gases}

The chemical composition of dissolved gases (Tab. 3) was largely dominated by atmospheric-related compounds, i.e., $\mathrm{N}_{2}$ (from 569 to $589 \mathrm{~mol} \mathrm{~L}^{-1}$ ) and $\mathrm{O}_{2}$ (from 216 to $329 \mathrm{~mol} \mathrm{~L}^{-1}$ ), with minor amounts of noble gases (Ar and $\mathrm{Ne}$ up to 15 and $0.008 \mathrm{~mol} \mathrm{~L}^{-1}$, respectively). Extra-atmospheric gas species mainly consisted of $\mathrm{CO}_{2}$, whose concentrations were from 2.1 to $81 \mathrm{~mol} \mathrm{~L}^{-1}$ ) significantly increased with depth, and relatively low $\mathrm{CH}_{4}$ concentrations (up to $21 \mathrm{~mol} \mathrm{~L}^{-1}$ ) in the deepest water layers $\left(\geq 35 \mathrm{~m}\right.$ depth). $\delta^{13} \mathrm{C}-\mathrm{CO}_{2 \mathrm{aq}}$ values (measured in dissolved gas samples collected from depth $\geq 20 \mathrm{~m}$ ) ranged

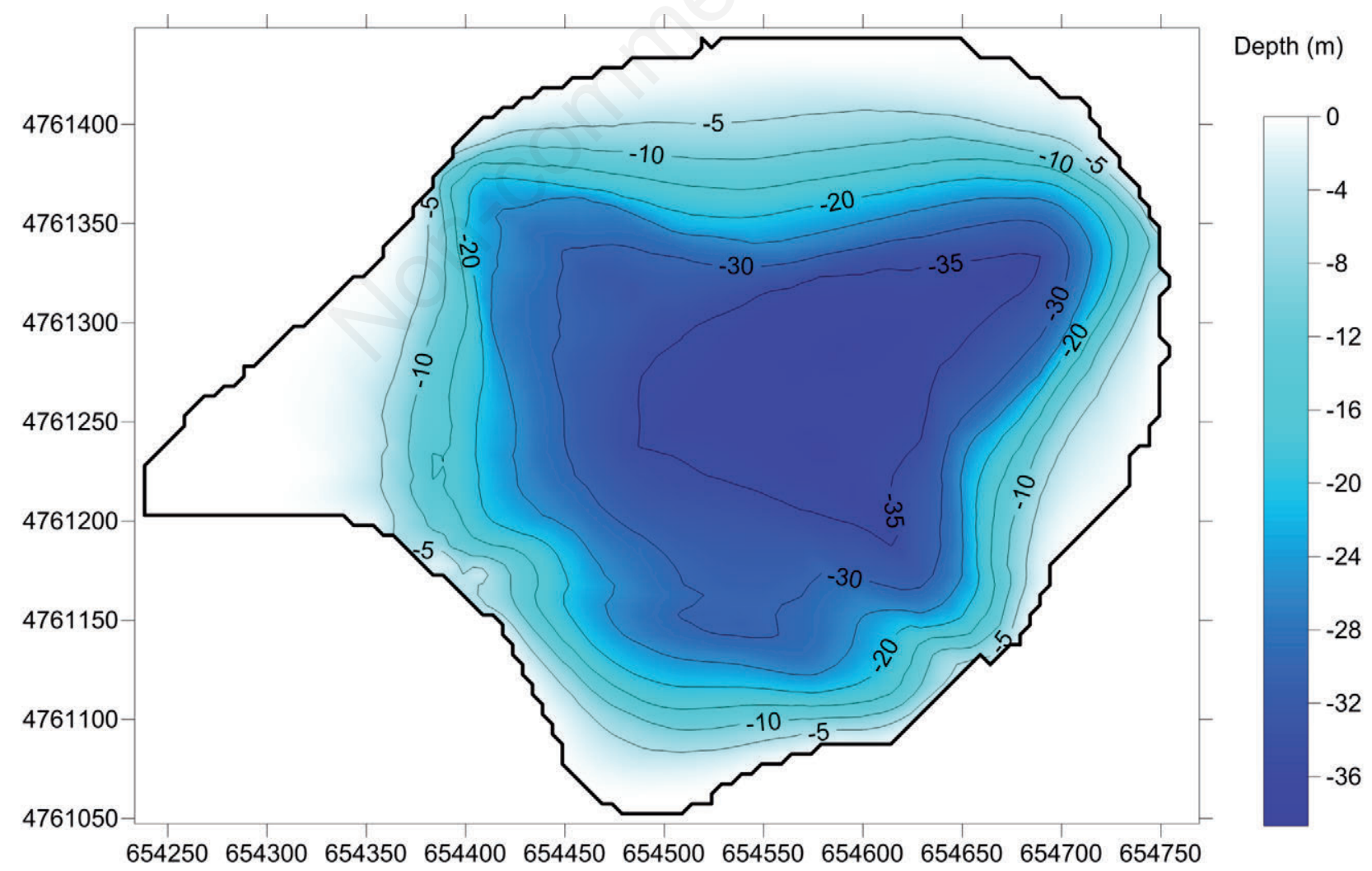

Fig. 3. Bathymetric map of Lake Accesa. 
from - 11.79 to $-9.24 \%$ vs V-PDB, whereas the $\delta^{13} \mathrm{C}_{-} \mathrm{CH}_{4}$ values were -68.5 and $-71.3 \%$ vs V-PDB at the depths of 35 and $38.4 \mathrm{~m}$, respectively.

\section{DISCUSSION}

\section{Processes controlling the lake water chemistry}

The most striking chemical feature of Lake Accesa water is its high salinity (TDS values $>2000 \mathrm{mg} \mathrm{L}^{-1}$ ), significantly higher than that of sinkhole lakes (Nisio et al., 2007; Caramanna et al., 2008; Tassi et al., 2012), and other types of lakes in Italy (Ambrosetti et al., 1992; Guilizzoni and Lami, 1992; Marchetto et al., 1995; Salmaso and Mosello, 2010), including those hosted in volcanic systems (Mosello et al., 2004; Ellwood et al., 2009; Cabassi et al., 2013), which are typically mainly fed by meteoric water. Few exceptions are the Vescovo lakes in the Pontina Plain (Central Italy) that have a $\mathrm{Na}^{+}-\mathrm{Cl}^{-}$composition and TDS values $>2000 \mathrm{mg} \mathrm{L}^{-1}$ (Tuccimei et al., 2005), and some small sinkhole lake in the S. Vittorino Plain (Rieti province, Central Italy) that show chemical features resembling those of Lake Accesa (Nisio et al., 2007; Caramanna et al., 2008). In both cases, the water chemical composition was interpreted as related to inputs of hydrothermal fluids.

The $\mathrm{Ca}-\mathrm{SO}_{4}$ composition of Lake Accesa water closely resembles those shown by thermal springs of Central Italy, which are fed by hydrothermal reservoirs

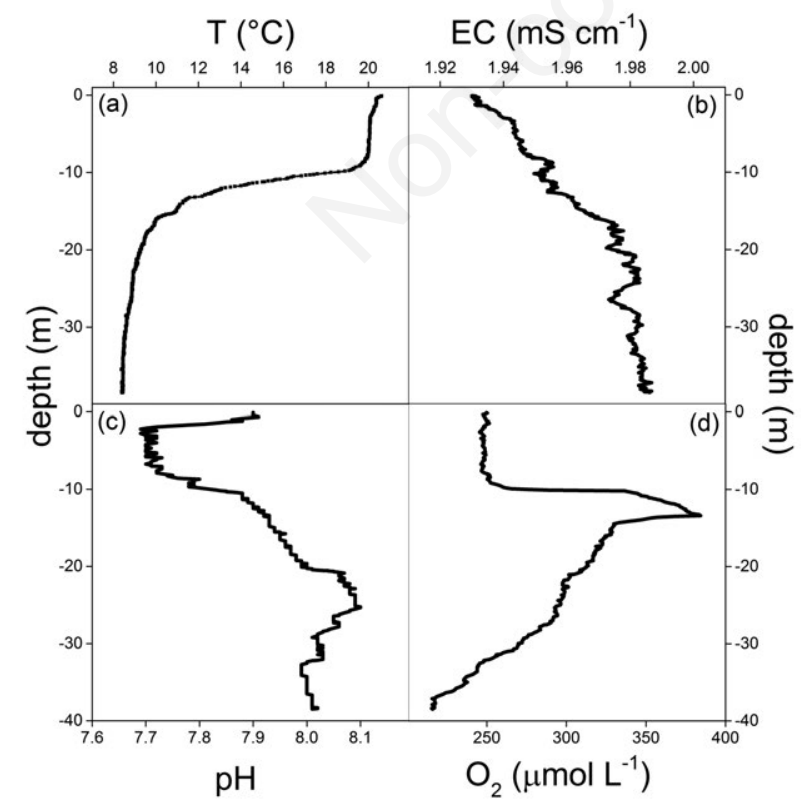

Fig. 4. Vertical profiles of a) temperature $\left(\mathrm{T} ;{ }^{\circ} \mathrm{C}\right)$; b) electrical conductivity $\left.\left.\left(\mathrm{EC} ; \mathrm{mS} \mathrm{cm}^{-1}\right) ; \mathrm{c}\right) \mathrm{pH} ; \mathrm{d}\right)$ dissolved oxygen $\left(\mathrm{O}_{2}\right.$; mol L ${ }^{-1}$ ) of Lake Accesa. recharged by meteoric water interacting with carbonateevaporite embedding formations (Bencini et al., 1977; Minissale and Duchi, 1988; Celati et al., 1990, Capaccioni et al., 2001; Boschetti et al., 2005), including the Aronna spring (Tab. 1) and other mineral water discharges, e.g. Venelle and Montioni, located nearby the study area (Minissale, 2004) (Fig. 1b). This suggests that all the mineral springs of the study area are related to the same hydrological circuit that also feeds the springs discharging from the lake bottom. Accordingly, modifications of the hydrologic cycle caused by the opening of galleries draining Niccioleta and Boccheggiano mine waters have caused a significant change of the outflow rate of these mineral springs (Tesser, 2012). Considering that: i) spring waters have a salinity up to two orders of magnitude higher than that of rainwater and show significant $\mathrm{CO}_{2}$ contents (Tab. 3); and ii) the lake have a marked thermocline, the lack of significant variations in water chemistry along the lake vertical profile (Tab. 1) is quite peculiar. Water density indeed increases with both increasing salinity and dissolved $\mathrm{CO}_{2}$ (Imboden and Wüest, 1995), and is inversely correlated to water temperature (Wüest et al., 1996). According to the classification proposed by Hutchinson (1957), inflow at depth of saline water in lakes is able to cause ectogenic meromixis, crenogenically meromictic lakes owe their permanent stratification to inflow of surface water runoff, whereas thermobaric stratification can occur when solar radiation produces a vertical gradient of lake water temperature. Water vertical convection at Lake Accesa is possibly related on the input rates from the different water sources, i.e. sublacustrine springs and rainwater, that can be evaluated on the basis of a simple hydrological balance of lake water. According to the observations reported in literature (Magny et al., 2007; Negri, 2008) and those carried out for the present study, the volume of Lake Accesa (V) can reasonably be as-

Tab. 2. Isotopic composition $\left(\delta^{18} \mathrm{O}, \delta^{2} \mathrm{H},{ }^{3} \mathrm{H}, \delta^{13} \mathrm{C}\right.$-TDIC and $\delta^{34} \mathrm{~S}$ ) of water samples collected from the vertical profile of Lake Accesa at depth intervals of $5 \mathrm{~m} . \delta^{34} \mathrm{~S}$ values for the Aronna spring are also reported.

\begin{tabular}{lcccccc}
\hline Sample & Depth & $\delta^{18} \mathrm{O}$ & $\delta^{2} \mathrm{H}$ & ${ }^{3} \mathrm{H}$ & $\delta^{13} \mathrm{C}-\mathrm{TDIC}$ & $\delta^{34} \mathrm{~S}$ \\
\hline Lake Accesa & 0 & -5.76 & -40.2 & nd & -1.10 & 13.70 \\
“ & 5 & -5.72 & -39.1 & nd & 0.33 & nd \\
“ & 10 & -5.82 & -37.8 & nd & -2.50 & nd \\
“ & 15 & -5.79 & -40.1 & 3 & -0.80 & 13.97 \\
“ & 20 & -5.8 & -42.4 & nd & -1.99 & nd \\
“ & 25 & -5.94 & -40.2 & nd & -2.14 & nd \\
“ & 30 & -5.79 & -38.7 & nd & -2.25 & nd \\
& 35 & -5.75 & -38.1 & nd & -2.47 & 14.12 \\
\hline Aronna & 38.4 & -5.79 & -38.0 & nd & -0.86 & nd \\
\hline
\end{tabular}

nd, not detected. 
sumed constant in the last decades. At a first approximation, under a steady-state condition, the water mass budget (MB) of the lake is equal to 0 and can be expressed in a differential form, as follows:

$\mathrm{MB}=0=\mathrm{Q}_{\mathrm{r}}+\mathrm{Q}_{\mathrm{sp}}-\mathrm{Q}_{\mathrm{e}}-\mathrm{Q}_{\mathrm{s}}-\mathrm{Q}_{\mathrm{et}}-\mathrm{Q}_{\mathrm{o}}$

where $Q_{r}$ is the amount of rainwater in the catchment area, $\mathrm{Q}_{\mathrm{sp}}$ is the water input from the sublacustrine springs, $\mathrm{Q}_{\mathrm{e}}$ is the evaporative loss of water from the lake surface, $Q_{\mathrm{et}}$ of rainwater loss from the soil of the catchment area due to evapotranspiration, $Q_{s}$ is the seepage water loss from the lake, $Q_{0}$ is the overflow flux through the Bruna River.

According to our measurements, the discharge rate of the Bruna River $\left(\mathrm{Q}_{\mathrm{o}}\right)$ is $9.5 \cdot 10^{6} \mathrm{~m}^{3} \mathrm{yr}^{-1}$. Assuming that the mean rainfall rate in this areas is $745 \mathrm{~mm} \mathrm{yr}^{-1}$ (Vannière et al., 2008), and considering that the catchment area of the lake is $5 \cdot 10^{6} \mathrm{~m}^{2}, \mathrm{Q}_{\mathrm{r}}$ is equal to $3.7 \cdot 10^{6} \mathrm{~m}^{3} \mathrm{yr}^{-1}$, although this value is to be considered overestimated since a significant percentage of rainwater infiltrates through soil and does not reach the lake. $Q_{e}$, calculated using the annual mean temperature $\left(13^{\circ} \mathrm{C}\right.$; Vannière et al., 2008) and the approach suggested by Dragoni and Valigi (1994), is $2.5 \cdot 10^{5} \mathrm{~m}^{3} \mathrm{yr}^{-1}$, whereas $\mathrm{Q}_{\mathrm{e}}$, calculated using the Thornthwaite equation (Thornthwaite, 1948), is $2.9 \cdot 10^{6} \mathrm{~m}^{3} \mathrm{yr}^{-1}$. The $\mathrm{Q}_{\mathrm{s}}$ value is likely to be considered negligible with respect to the other input and output factors, since the bottom of the lake is almost impermeable being covered by a thick silt layer (Negri, 2008). Therefore, solving eq. (2) sublacustrine spring discharges into Lake Accesa $\left(\mathrm{Q}_{\mathrm{sp}}\right)$ is calculated at $8.95 \cdot 10^{6} \mathrm{~m}^{3} \mathrm{yr}^{-1}$, a value that is higher with respect to most thermal springs in Tuscany and comparable with those of the Aronna and Venelle springs (Celati et al., 1990). As expected, $Q_{\text {sp }}$ basically constitutes the main water source for the lake, since it is more than one order of magnitude higher than the net amount of rainwater input into the lake $\left(\mathrm{Q}_{\mathrm{r}}\right.$ $\left.\mathrm{Q}_{\mathrm{et}}\right)$. Moreover, our data indicate that the theoretical re- newal time of Lake Accesa water, i.e., the ratio between the volume of the lake and the volume of its outflow, is $<3$ months, which suggests a relatively high hydrological vivacity that contributes to counteract the establishment of a chemical stratification (Ambrosetti et al., 2003).

As shown in the $\delta^{2} \mathrm{H} v s \delta^{18} \mathrm{O}$ diagram (Fig. 5), Lake Accesa, as well as the Aronna spring (Minissale and Vaselli, 2011), is characterized by a $\delta^{18} \mathrm{O}$ positive shift with respect to the Local Meteoric Water Line (LMWL)

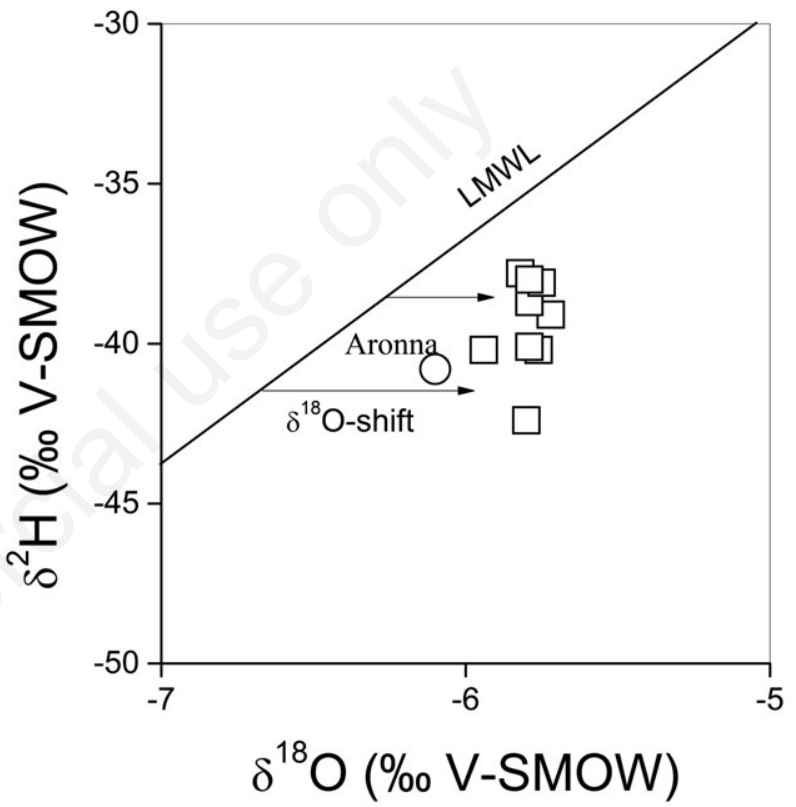

Fig. 5. $\delta^{2} \mathrm{H} v s \delta^{18} \mathrm{O}$ binary diagram for Lake Accesa (open square) and Aronna (open circle) waters. The Local Meteoric Water Line (LMWL) proposed by Longinelli and Selmo (2003) for Central Italy is also reported.

Tab. 3. Chemical and isotopic $\left(\delta^{13} \mathrm{C}-\mathrm{CO}_{2}\right.$ and $\left.\delta^{13} \mathrm{C}_{-}-\mathrm{CH}_{4}\right)$ compositions of dissolved gases collected from the vertical profile of Lake Accesa at depth intervals of $5 \mathrm{~m}$. Concentrations of dissolved gases are in $\mathrm{mol} \mathrm{L}^{-1}$. Dissolved gas composition for the Aronna spring is also reported.

\begin{tabular}{|c|c|c|c|c|c|c|c|c|c|c|}
\hline Sample & Depth & $\mathrm{CO}_{2}$ & $\mathrm{~N}_{2}$ & $\mathrm{CH}_{4}$ & $\mathrm{Ar}$ & $\mathrm{O}_{2}$ & $\mathrm{Ne}$ & $\delta^{13} \mathrm{C}-\mathrm{CO}_{2 \mathrm{aq}}$ & $\delta^{13} \mathrm{C}-\mathrm{CH}_{4}$ & TOT \\
\hline Lake Accesa & 0 & 2.1 & 589 & nd & 15 & 250 & 0.008 & nd & nd & 856 \\
\hline “ & 5 & 9.3 & 578 & nd & 15 & 249 & 0.008 & nd & nd & 851 \\
\hline “ & 10 & 12 & 569 & nd & 14 & 275 & 0.008 & nd & nd & 870 \\
\hline “ & 15 & 15 & 581 & nd & 14 & 329 & 0.008 & nd & nd & 939 \\
\hline “ & 20 & 39 & 578 & nd & 15 & 313 & 0.008 & -11.8 & nd & 945 \\
\hline “ & 25 & 45 & 582 & nd & 14 & 296 & 0.007 & -9.24 & nd & 937 \\
\hline “ & 30 & 49 & 577 & nd & 14 & 270 & 0.007 & -11.1 & nd & 910 \\
\hline “ & 35 & 58 & 572 & 13 & 14 & 238 & 0.007 & -11.6 & -68.5 & 895 \\
\hline “ & 38.4 & 81 & 570 & 21 & 14 & 216 & 0.007 & -11.7 & -71.3 & 902 \\
\hline Aronna & & 615 & 455 & 0.54 & 10 & 61 & 0.007 & -12.2 & nd & 1142 \\
\hline
\end{tabular}

nd, not detected. 
proposed by Longinelli and Selmo (2003) for Central Italy, indicating the occurrence of a significant interaction with rocks. Furthermore, the water isotopic data confirm that the origin of lake water and the Aronna spring are intimately related, and indicate that meteoric water feeding the deep hydrothermal system permeate into the soil at an altitude of $\sim 200-400 \mathrm{~m}$. The nearby Colline Metallifere (Fig. 1) likely represents the main recharge area, as also supported by the ${ }^{3} \mathrm{H}$ concentration (3 TU), suggesting that Lake Accesa is a mix of submodern (i.e., prior to 1950s) and modern water. Rainwater permeating at depth interacts with the Mesozoic carbonate sequence and anhydriterich Triassic layers. Dissolution of $\mathrm{CaMg}\left(\mathrm{CO}_{3}\right)_{2}$ and $\mathrm{Ca}(\mathrm{Mg}) \mathrm{SO}_{4}$ produces the relatively high TDS values characterizing Lake Accesa. The $\mathrm{Ca}-\mathrm{SO}_{4}$ composition is produced by subsequent calcite and dolomite precipitation that controls the $\mathrm{HCO}_{3}{ }^{-}$concentrations, whereas $\mathrm{SO}_{4}{ }^{-}$ bearing minerals (gypsum and anhydrites) are under-saturated (Tab. 4). The difference between the $\delta^{13} \mathrm{C}$-TDIC values of the lake (Tab. 2) and the $\delta^{13} \mathrm{C}$ values of carbonate minerals in this region (from +1.5 to $+3.5 \%$ vs VPDB; Cortecci and Lupi, 1994) is produced during the dissolution process that at $25^{\circ} \mathrm{C}$ causes an isotopic fractionation of $2.4 \%$ (Bottinga, 1968). Similarly, the variations of the $\delta^{13} \mathrm{C}$-TDIC values measured along the lake vertical profile are possibly related to secondary calcite and dolomite precipitation. The $\delta^{34} \mathrm{~S}^{-} \mathrm{SO}_{4}$ values (Tab. 2) are slightly less positive than those of the Triassic anhydrites ranging from $+15 \%$ to $+20 \%$ vs V-CDT (Cortecci et al., 1981; Dinelli et al., 1999), confirming that waterrock interactions involving this evaporitic formation is the dominant source of $\mathrm{SO}_{4}{ }^{2-}$ for Lake Accesa. However, considering that isotopic fractionation caused by dissolution of solid sulfates in water is negligible (Tuttle et al., 2009), minor sulfur contribution from ${ }^{32} \mathrm{~S}$-rich sulfide deposits (Cortecci et al., 1983) cannot be excluded. This hypothe-

Tab. 4. Saturation indices for calcite, dolomite, anhydrite and gypsum calculated for Lake Accesa water at depth intervals of $5 \mathrm{~m}$ using the PHREEQC v2.18 software package (Parkhurst and Appelo, 1999).

\begin{tabular}{lccccc}
\hline Sample & Depth & $\begin{array}{c}\text { SI } \\
\text { Dolomite }\end{array}$ & $\begin{array}{c}\text { SI } \\
\text { Calcite }\end{array}$ & $\begin{array}{c}\text { SI } \\
\text { Anhydrite }\end{array}$ & $\begin{array}{c}\text { SI } \\
\text { Gypsum }\end{array}$ \\
\hline Lake Accesa & 0 & 2.03 & 1.21 & -0.52 & -0.17 \\
“ & 5 & 1.96 & 1.16 & -0.53 & -0.18 \\
“ & 10 & 1.64 & 1.01 & -0.54 & -0.19 \\
“ & 15 & 1.73 & 1.12 & -0.61 & -0.16 \\
“ & 20 & 1.75 & 1.14 & -0.62 & -0.15 \\
“ & 25 & 1.88 & 1.21 & -0.63 & -0.15 \\
& 30 & 1.75 & 1.15 & -0.62 & -0.14 \\
& 35 & 1.71 & 1.12 & -0.63 & -0.14 \\
& 38.4 & 1.70 & 1.12 & -0.63 & -0.14 \\
\hline
\end{tabular}

SI, saturation indices. sis is also supported by the anomalously high $\Sigma \mathrm{S}^{2-}$ concentrations measured both in the lake and Aronna waters (Tab. 1), even higher than most of the $\mathrm{SO}_{4}{ }^{2-}-$ rich springs in Italy (Montegrossi et al., 2006). This chemical feature is likely related to leakage of S-bearing polymetallic minerals from the nearby mining area of Fenice Capanne. Production of reduced S-bearing chemical species from microbial activity is indeed expected to be negligible, since the lake lacks of anaerobic layers (Tab. 3) where $\mathrm{SO}_{4}{ }^{2-}$ reduction can occur.

Dissolution of carbonates and sulfates is the main source for the relatively high concentrations of $\mathrm{Sr}^{2+}$ (up to $7.2 \mathrm{mg} / \mathrm{L}$ ), typically substituting $\mathrm{Ca}^{2+}$ in crystal lattice of these minerals. The relatively low concentrations of $\mathrm{Na}^{+}$ and $\mathrm{Cl}^{-}$, which are the typical main constituents of geothermal fluids, suggest that contribution of deep geothermal fluids from the Larderello-Travale geothermal systems that are located only 30 kilometers N-W of Lake Accesa, are unlike.

\section{Origin of dissolved gases}

As already mentioned, lake water chemistry does not show significant changes along the vertical profile. On the contrary, the composition of dissolved gases, which is largely dominated by atmospheric gases maintaining the same concentrations at different depths (Tab. 3), is marked by increasing dissolved $\mathrm{CO}_{2}$ concentrations and, at $>30$ $\mathrm{m}$ depth, by the presence of significant amounts of $\mathrm{CH}_{4}$. Carbon dioxide and $\mathrm{CH}_{4}$ are commonly produced in lakes by microbial activity.

Production of $\mathrm{CO}_{2}$ from decomposition of organic matter through microbial activity can occur at both anaerobic and aerobic conditions (Rudd et al., 1974; Rich, 1975; Hanson and Hanson, 1996; Lopes et al., 2011). These processes are counteracted by $\mathrm{CO}_{2}$ consumption that in the epilimnion proceeds through oxygenic photosynthesis mainly carried out by microalgae and cyanobacteria (Nelson and Ben-Shem, 2004), whereas at anaerobic conditions is mainly related to the activity of methanogens, a group of microorganisms phylogenetically affiliated to the kingdom Euarchaeota of the domain Archaea (Woese et al., 1990). Considering i) the availability of free $\mathrm{O}_{2}$ along the whole vertical profile, excluding the occurrence anaerobic processes; and ii) the relatively high concentrations of dissolved $\mathrm{CO}_{2}$ measured in Aronna spring whose chemistry is evidently similar to that of the sublacustrine discharges, $\mathrm{CO}_{2}$ in Lake Accesa likely has an external origin. Moreover, the $\square \delta^{13} \mathrm{C}-\mathrm{CO}_{2 \mathrm{aq}}$ values of the lake are similar to those characterizing most $\mathrm{CO}_{2}$-rich springs of central Italy (Minissale et al., 2002, and references therein). Therefore, the origin of $\mathrm{CO}_{2}$ may be related to mixing of deep hydrothermal fluids, having $\square \delta^{13} \mathrm{C}-\mathrm{CO}_{2}$ values that range from -2 to $+3 \%$ vs $\mathrm{V}$ PDB, with isotopically light $\mathrm{CO}_{2}(<-20 \%$ vs $\mathrm{V}-\mathrm{PDB})$ 
likely deriving from a shallow biogenic source (Deines et al., 1974; Rose and Davisson, 1996) and/or from isotopic carbon fractionation caused by limestone precipitation affecting deep uprising fluids (Minissale, 2004). It is worth noting that the differences between $\delta^{13} \mathrm{C}$-TDIC and $\delta^{13} \mathrm{C}$ $\mathrm{CO}_{2 \mathrm{aq}}$ values (Tabs. 2 and 3, respectively) are consistent with the values $(9-10 \%$ ) theoretically predicted for isotopic fractionation occurring during the transformation of dissolved $\mathrm{CO}_{2}$ into $\mathrm{HCO}_{3}^{-}$(Mook et al., 1974).

The extremely negative carbon isotopic signature of $\mathrm{CH}_{4}$ (Tab. 3) clearly indicates that this gas originates from methanogenic activity (Schoell, 1980; Whiticar, 1999), a process that in the hypolimnion of lakes typically proceeds through $\mathrm{CO}_{2}$ reduction (Belyaev et al., 1975; Winfrey et al., 1977; Schoell et al., 1988). Therefore, $\mathrm{CH}_{4}$ is produced within the bottom sediments and is released to the lake through diffusion and/or carried by the sublacustrine springs. Once in the lake, $\mathrm{CH}_{4}$ is readily oxidized, as also testified by the decrease of $\mathrm{O}_{2}$ concentrations (Tab. 3), indicating the occurrence of $\mathrm{O}_{2}$-consuming reactions.

\section{CONCLUSIONS}

Lake Accesa is hosted in a basin produced by karst collapse(s) whose origin is likely related to sub-surface circulation of $\mathrm{Ca}-\mathrm{SO}_{4}$ fluids produced by interaction of meteoric water with rocks of Mesozoic carbonate and Triassic evaporite formations. These fluids represent the main water source for the lake, whereas direct contribution of rainwater accounts for less than $10 \%$ of the total water inflow. This hydrological cycle (Fig. 6) depends on the local structural assessment consisting of NNW and ENE-oriented fault systems. As a result, the total outflow of mineral water from the study area is one of the highest of Tuscany (Celati et al., 1990) and in general of the Tyrrhenian side of central-southern Italy (Minissale, 2004). The occurrence of relatively high saline sublacustrine springs that discharge into $\mathrm{CO}_{2}$-rich Lake Accesa and a pronounced thermocline (Fig. 4a) could determine favorable conditions for a density gradient able to produce a chemical stratification. Italian lakes having morphological features similar to those of Lake Accesa, i.e., Averno and Monticchio Lakes (Cabassi et al., 2013), are meromictic.

Notwithstanding these evidences, at Lake Accesa no significant variations of water chemistry with depth were recognized. A possible explanation is that the huge amount of mineral water recharging the lake from depth and then discharged through the Bruna River, which determines a relatively short renewal time for lake water $(<3$ months), is able to promote convective mixing of the water column. A continuous vertical circulation allows oxygenated shallow waters to reach the deep lake waters, preventing decomposition of organic material and dissolution of its end product that could contribute to enhance a vertical density gradient (Boehrer and Schultze, 2008). However, the vertical water mixing cannot prevent the instauration of a thermocline during the warm season, when solar radiation is able to rapidly increase the temperature of the shallow water layer thus seasonally maintaining a temperature vertical gradient.

The peculiar chemistry of Lake Accesa is the result of a complex combination of geostructural assessment, hydrological patterns and geochemical processes. Past experiences (Tesser, 2012) have shown that changes of the water drainage system in the nearby mining district have a strong influence on the deep-originated water supply for the lake,



Fig. 6. Schematic model for the hydrological cycle of Lake Accesa. 
thus possible future intervention should be carefully evaluated to preserve this unique natural environment.

\section{ACKNOWLEDGMENTS}

The work was financially supported by the Laboratories of Fluid and Rock Geochemistry (Resp. F. Tassi) and Stable Isotopes (Resp. O. Vaselli). The authors are grateful to Giuliano Pieretti for his help in field, Dr. S. Caliro and Dr. G. Moratti for the construction of the bathymetric profile of Lake Accesa. The authors wish to thanks two anonymous reviewers for their useful comments to an early version of the manuscript.

\section{REFERENCES}

Ambrosetti W, Barbanti L, Mosello R, Pugnetti A, 1992. Limnological studies on the deep southern alpine lakes Maggiore, Lugano, Como, Iseo and Garda. Mem. Ist. Ital. Idrobiol. 50:117-146.

Ambrosetti W, Barbanti L, Sala N, 2003. Residence time and physical processes in lakes. J. Limnol. 62(Suppl. 1):1-15.

Arisi Rota F, Vighi L, 1971. [Giacimenti minerari].[Article in Italian]. Rend. Soc. It. Miner. Petrol. 37 (Spec. Issue):357-544.

Batini F, Brogi A, Lazzarotto A, Liotta D, Pandeli E, 2003. Geological features of Larderello-Travale and Mt. Amiata geothermal areas (southern Tuscany, Italy). Episodes 26:239-244.

Belyaev SS, Finkelstein ZI, Ivanov MV, 1975. Intensity of bacterial methane formation in ooze deposits of certain lakes. Microbiol. 44:272-275.

Bellani S, Brogi A, Lazzaretto A, Liotta D, Ranalli G, 2004. Heat flow, deep temperatures and extensional structures in the Larderello Geothermal Field (Italy): constraints on geothermal fluid flow. J. Volcanol. Geotherm. Res. 132:15-29.

Bencini A, Duchi V, Martini M, 1977. Geochemistry of thermal springs of Tuscany (Italy). Chem. Geol. 19:229-252.

Benvenuti M, Morelli F, Corsini F, Masotti A, Lattanzi P, Tanelli G, 1994. New isotopic data on the pyrite ( \pm cu-pb-zn) deposit of Campiano (southern Tuscany). Mem. Soc. Geol. It. 48:691-697.

Bertini G, Cameli GM, Costantini A, Decandia FA, Di Filippo M, Dini I, Elter FM, Lazzarotto A, Liotta D, Pandeli E, Sandrelli F, Toro B, 1991. [Struttura geologica fra i Monti di Campiglia e Rapolano Terme (Toscana Meridionale): stato attuale delle conoscenze e problematiche].[ Article in Italian]. Studi Geol. Camerti Spec. Issue 1:155-178.

Billi A, Valle A, Brilli M, Faccenna C, Funiciello R, 2007. Fracture-controlled fluid circulation and dissolutional weathering in sinkhole-prone carbonate rocks from central Italy. J. Struct. Geol. 29:385-395.

Boehrer B, Schultze M, 2008. Stratification of lakes. Rev. Geophys. 46:RG2005.

Boschetti T, Venturelli G, Toscani L, Mucchino C, 2005. The Bagni di Lucca thermal waters (Tuscany, Italy): an example of $\mathrm{Ca}-\mathrm{SO}_{4}$ waters with high $\mathrm{Na} / \mathrm{Cl}$ and low $\mathrm{Ca} / \mathrm{SO}_{4}$ ratios. J. Hydrol. 307:270-293.

Bottinga Y, 1968. Calculation of fractionation factors for carbon and oxygen isotopic exchenge in the system calcite-carbon dioxide-water. J. Phys. Chem. 72:800-808.
Brogi A, Lazzarotto A, Liotta D, 2005. Results of the CROP 18 Project. Boll. Soc. Geol. It. 3:239.

Cabassi J, Tassi F, Vaselli O, Fiebig J, Nocentini M, Capecchiacci F, Rouwet D, Bicocchi G, 2013. Biogeochemical processes involving dissolved $\mathrm{CO}_{2}$ and $\mathrm{CH}_{4}$ at Albano, Averno, and Monticchio meromictic volcanic lakes (CentralSouthern Italy). Bull. Volcanol. 75:683-702.

Caramanna G, Ciotoli G, Nisio S, 2008. A review of natural sinkhole phenomena in Italian plain areas. Natural Hazards 45:145-172.

Capaccioni B, Didero M, Paletta C, Salvatori P, 2001. Hydrogeochemistry of groundwaters from carbonate formations with basal gypsiferous layers: an example from the Mt. Catria - Mt Nerone ridge (Northern Appenines, Italy). J. Hydrol. 253:14-26.

Carmignani L, Decandia FA, Fantozzi PF, Lazzarotto A, Liotta D, Meccheri M, 1994. Tertiary extensional tectonics in Tuscany (Northern Apennines, Italy). Tectonophysics 238:295315 .

Carmignani L, Decandia FA, Disperati L, Fantozzi PL, Lazzarotto A, Lotta D, Oggiano G, 1995. Relationships between the Tertiary structural evolution of the Sardinia Corsica Provencal Domain and the Northern Apennines. Terra Nova 7:128-137.

Carmignani L, Oggiano G, Barca S, Conti P, Salvadori I, Eltrudis A, Funedda A, Pasci S, 2001. [Geologia della Sardegna. Note illustrative della Carta Geologica della Sardegna a scala 1:200000].[Memorie descrittive della Carta Geologica d'Italia, 60].[Book in Italian]. Istituto Poligrafico e Zecca dello Stato: 283 pp.

Celati S, Grassi S, Calore C, 1990. Overflow thermal springs of Tuscany, Italy. J. Hydrol. 118:191-207.

Chiodini G, 1996. Gases dissolved in groundwaters: analytical methods and examples of applications in central Italy, p. 135-148. Proceeding Symp. Environmental Geochemistry, Castelnuovo di Porto, Rome, Italy.

Coleman ML, Sheperd TJ, Rouse JE, Moore GR, 1982. Reduction of water with zinc for hydrogen isotope analysis. Anal. Chem. 54:993-995.

Cortecci G, Klemm, DD, Lattanzi P, Tanelli G, Wagner J, 1983. A sulfur isotope study on pyrite deposits of southern Tuscany, Italy. Mineral. Deposita 18:285-297.

Cortecci G, Lupi L, 1994. Carbon, oxygen and strontium isotope geochemistry of carbonates rocks from the Tuscan Nappe, Italy. Mineral. Petrogr. Acta, 37:63-80.

Cortecci G, Reyes E, Berti G, Casati P, 1981. Sulfur and oxygen isotopes in Italian marine sulfate of Permian and Triassic age. Chem. Geol. 34:65-79.

Costagliola P, Benvenuti M, Chiarantini L, Bianchi S, Di Benedetto F, Paolieri M, Rossato L, 2008. Impact of ancient metal smelting on arsenic pollution in the Pecora River Valley, southern Tuscany, Italy. Appl. Geochem. 23:1241-1259.

Deines P, Langmuir D, Harmon RS, 1974. Stable carbon isotope ratios and the existence of a gas phase in the evolution of carbonate groundwaters. Geochim. Cosmochim. Acta 38:1147-1164.

Del Prete S, Di Crescenzo G, Santangelo N, Santo A, 2010. Karst sinkholes in Campania (southern Italy): geo-structural analysis, predisposing factors and genetic hypothesis. Zeitschr. Geomorphol. 54:259-284. 
Dinelli E, Testa G, Cortecci G, Barbieri M, 1999. Stratigraphic and petrographic constraint to traced element and isotope geochemistry of Messinian sulphates of Tuscany. Mem. Soc. Geol. Ital. 54:61-74.

Dini A, Gianelli G, Puxeddu M, Ruggieri G, 2005. Origin and evolution of Pliocene-Pleistocene granites from the Larderello geothermal field (Tuscan Magmatic Province, Italy). Lithos 81:1-31.

Dragoni W, Valigi D, 1994. Contributo alla stima dell'evaporazione dalle superfici liquide in Italia Centrale. Geologia Romana 30:151-158.

Duchi V, Minissale A, Rossi A, 1986. Chemistry of thermal springs in the Larderello-Travale geothermal region, southern Tuscany, Italy. App. Geochem. 1:659-667.

Ellwood TW, Albertano P, Galvez R, Funiciello R, Mosello R, 2009. Water chemistry and trophic evaluation of Lake Albano (Central Italy): a four year water monitoring study. J. Limnol. 68:288-303.

Elter P, Giglia G, Tongiorgi M, Trevisan L, 1975. Tensional and compressional areas in the recent (Tortonian to present) evolution of the Northern Apennines. Boll. Geofis. Teor. Appl. 42:3-18.

Epstein S, Mayeda TK, 1953. Variation of the ${ }^{18} \mathrm{O} /{ }^{16} \mathrm{O}$ ratio in natural waters. Geochim. Cosmochim. Acta 4:213-224.

Evans WC, White LD, Rapp JB, 1998. Geochemistry of some gases in hydrothermal fluids from the southern Juan de Fuca ridge. J. Geophys. Res. 15:305-313.

Frondini F, Caliro S, Cardellini C, Chiodini G, Morgantini N, Parello F, 2008. Carbon dioxide degassing from Tuscany and northern Latium (Italy). Global Planet. Change 61: 89-102.

Gianelli G, Manzella A, Puxeddu M, 1997. Crustal models of the geothermal areas of southern Tuscany (Italy). Tectonics 281:221-239.

Guilizzoni P, Lami A, 1992. Historical records of changes in the chemistry and biology of Italian lakes. In: P. Guilizzoni, G. Tartari and G. Giussani (eds.), Limnology in Italy. Mem. Ist. Ital. Idrobiol. 50:61-77.

Hanson RS, Hanson TE, 1996. Methanotrophic bacteria. Microbiol. Rev. 60:439-471.

Hutchinson GE, 1957. A treatise on limnology. 1. Geography, physics and chemistry. J. Wiley: $1015 \mathrm{pp}$.

Imboden DM, Wüest A, 1995. Mixing mechanisms in lakes, $p$. 83-138. In: A. Lerman, D.M. Imbonden and J.R. Gat (eds.), Physics and chemistry of lakes. Springer.

Jolivet L, Faccenna C, Goffé B, Mattei M, Rossetti F, Brunet C, Storti F, Funiciello R, Cadet JP, Parra T, 1998. Mid-crustal shear zones in post-orogenic extension: the northern Tyrrhenian Sea case. J. Geophys. Res. 103:12123-12160.

Lattanzi P, Benvenuti M, Costagliola P, Tanelli G, 1994. An overview on recent research on the metallogeny of Tuscany, with special reference to the Apuane Alps. Mem. Soc. Geol. It. 48:613-625.

Liotta D, Ruggieri G, Brogi A, Fulignati P, Dini A, Nardini I, 2010. Migration of geothermal fluids in extensional terrains: the ore deposits of the Boccheggiano-Montieri area (Southern Tuscany, Italy). Int. J. Earth Sci. 99:623-644.

Lobell JA, 2002. Etruscan Pompeii (largest Etruscan settlement ever found discovered in the Tuscan plain near Lake Accesa, Italy). Archaeology 55:1-12.
Longinelli A, Selmo E, 2003. Isotopic composition of precipitations in Italy: a first overall map. J. Hydrol. 270:75-88.

Lopes F, Viollier E, Thiam A, Michard G, Abril G, Groleau A, Prévot F, Carrias J-F, Albéric P, Jézéquel D, 2011. Biogeochemical modeling of anaerobic $v s$ aerobic methane oxidation in a meromictic crater lake (Lake Pavin, France). Appl. Geochem. 26:1919-1932.

Magny M, de Beaulieu JL, Drescher-Schneider R, Vannière B, Walter-Simonnet A-V, Miras Y, Millet L, Bossuet G, Peyron O, Bruggiapaglia E, Leroux A, 2007. Holocene climate changes in central Mediterranean as recorded by lake-level fluctuations at Lake Accesa (Tuscany, Italy). Quaternary Sci. Rev. 26:1736-1758.

Marchetto A, Mosello R, Psenner R, Bendetta G, Boggero A, Tait D, Tartari GA, 1995. Factors affecting water chemistry of alpine lakes. Aquatic Sci. 57:81-89.

Mascaro I, Benvenuti M, Corsini F, Costagliola P, Lattanzi P, Parrini P, Tanelli G, 2001. Mine wastes at the polymetallic deposit of Fenice Capanne (Southern Tuscany, Italy). Mineralogy, geochemistry and environmental impact. Environ. Geol. 41:417-42.

Merciai G, 1933. [Il Lago dell'Accesa presso Massa Marittima].[Article in Italian]. Memorie Società Toscana di Scienze Naturali, Serie B 43:29-50.

Minissale A, 2004. Origin, transport and discharge of $\mathrm{CO}_{2}$ in central Italy. Earth Sci. Rev. 66:89-141.

Minissale A, Duchi V, 1988. Geothermometry on fluids circulating in a carbonate reservoir in north-central Italy. J. Volcanol. Geotherm. Res. 35:237-252.

Minissale A, Magro G, Vaselli O, Verrucchi C, Perticone I, 1997. Hydro-gas geochemistry of the Mt. Amiata silicic complex and surrounding areas (central Italy). J. Volcanol. Geotherm. Res. 79:223-251.

Minissale A, Vaselli O, 2011. Karst springs as "natural" pluviometers: Constrains on the isotopic composition of rainfall in the Apennines of Central Italy. Appl. Geochem. 26:838-852.

Minissale A, Vaselli O, Tassi F, Magro G, Grechi GP, 2002. Fluid mixing in carbonate aquifers near Rapolano (centralItaly): chemical and isotopic constraints. Appl. Geochem. 17: 1329-1342.

Montegrossi G, Tassi F, Vaselli O, Bidini E, Minissale A, 2006. A new, rapid and reliable method for the determination of reduced sulphur $\left(\Sigma \mathrm{S}^{2-}\right)$ species in natural discharges. Appl. Geochem. 21:849-857.

Mook WG, Bommerson JC, Staverman WH, 1974. Carbon isotope fractionation between dissolved bicarbonate and gaseous carbon dioxide. Earth Planet. Sci. Lett. 22:169-176.

Mosello R, Arisci S, Bruni P, 2004. Lake Bolsena (Central Italy): an updating on its water chemistry. J. Limnol. 63:1-12.

Negri M, 2008. [Nuove osservazioni geomorfologiche sul lago dell'Accesa (Massa Marittima, Toscana)].[Article in Italian]. Atti Mus. Stor. Nat. Maremma 22:105-118.

Nelson N, Be-Shem A, 2004. The complex architecture of oxygenic photosynthesis. Mol. Cell Biol. 5:1-12.

Nicolich R, 1989. Crustal structures from seismic studies in the frame of the European Geotraverse (southern segment) and CROP projects, p. 41-61. In: A. Boriani, M. Bonafede, G.B. Piccardo and G.B. Vai (eds). The lithosphere in Italy: advances in earth science research. Accademia Nazionale dei Lincei. 
Nisio S, Caramanna G, Ciotoli G, 2007. Sinkholes hazard in Italy: first results on the inventory and analysis of some case studies. In: M. Parise and J. Gunn (eds.), Natural and anthropogenic hazards in karst: recognition, analysis and mitigation. Geol. Soc. London Spec. Pub. 279:23-45.

Parkhurst DL, Appelo CAJ, 1999. User's guide to PHREEQC, ver. 2. A computer program for speciation, batch-reaction, one-dimensional transport, and inverse geochemical calculations. Investigations Report 99-4259. U.S. Geological Survey Water-Resources: 312 pp.

Rich PH, 1975. Benthic metabolism of a soft-water lake. Verh. Int. Verein Limnol. 19:1023-1028.

Rizzotto M, 1981. [Il Lago dell'Accesa (Grosseto) note floristiche e vegetazionali].[Article in Italian]. Atti Soc. Tosc. Sci. Nat. Mem. Serie B: 88.

Rose TP, Davisson ML, 1996. Radiocarbon in hydrologic systems containing dissolved magmatic carbon dioxide. Science 273:1367-1370.

Rossetti F, Aldega L, Tecce F, Balsamo F, Billi A, Brilli M, 2011. Fluid flow within the damage zone of the Boccheggiano extensional fault (Larderello-Travale geothermal field, central Italy): Structures, alteration and implications for hydrothermal mineralization in extensional settings. Geol. Mag. 148:558-579.

Rudd JWM, Hamilton RD, Campbell NER, 1974. Measurement of microbial oxidation of methane in lake water. Limnol. Oceanogr. 19:519-524.

Salata GG, Roelke LA, Cifuentes LA, 2000. A rapid and precise method for measuring stable carbon isotope ratios of dissolved inorganic carbon. Mar. Chem. 69:153-161.

Salmaso N, Mosello R, 2010. Limnological research in the deep southern subalpine lakes: synthesis, directions and perspectives. Adv. Ocean. Limnol. 1:29-66.

Santo A, Ascione A, Del Prete S, Di Crescenzo G, Santangelo N, 2011. Collapse sinkholes distribution in the carbonate massifs of Central and Southern Apennines. Acta Carsologica 40:95-112.

Sauro U, 2003. Dolines and sinkholes: aspects of evolution and problems of classification. Acta Carsologica 32:41-52.

Schoell M, 1980. The hydrogen and carbon isotopic composition of methane from natural gases of various origins. Geochim. Cosmochim. Acta 44:649-661.

Schoell M, Tietze K, Schoberth S, 1988. Origin of the methane in Lake Kivu (east-central Africa). Chem. Geol. 71:257-265.

Serri G, Innocenti F, Manetti P, 1993. Geochemical and petrological evidence of the subduction of delaminated Adriatic continental lithosphere in the genesis of the Neogene-Quaternary magmatism of central Italy. Tectonophysics 223: 117-147.

Serri G, Innocenti F, Manetti P, Tonarini S, Ferrara G, 1991. [I1 magmatismo neogenico-quaternario dell'area laziale-umbra: implicazioni sui modelli di evoluzione geodinamica dell'Appennino settentrionale].[Article in Italian]. Studi Geolog. Camerti 1:429-463.

Tanelli G, 1983. [Mineralizzazioni metallifere e minerogenesi della Toscana].[Article in Italian]. Mem. Soc. Geol. It. 25:91-109.
Tassi F, Vaselli O, Luchetti G, Montegrossi G, Minissale A, 2008. [Metodo per la determinazione dei gas disciolti in acque naturali], p. 1-12.[Article in Italian]. Int. Rep. CNRIGG Florence $\mathrm{n}^{\circ}$ 10450-11.

Tassi F, Vaselli O, Fernandez E, Duarte E, Martinez M, Delgado Huertas A, Bergamaschi F, 2009. Morphological and geochemical features of crater lakes in Costa Rica: an overview. J. Limnol. 68:193-205.

Tassi F, Cabassi J, Rouwet D, Paolozzi R, Marcelli M, Quartaro M, Capecchiacci F, Nocentini M, Vaselli O, 2012. Water and dissolved gas geochemistry of the monomictic Paterno sinkhole (central Italy). J. Limnol. 71:245-260.

Tesser E, 2012. [Monitoraggio e trattamento di drenaggi in miniera mediante filtrazione lenta].[PhD Thesis in Italian]. University of Basilicata: $186 \mathrm{pp}$.

Thornthwaite CW, 1948. An approach toward a rational classification of climate. Geograph. Rev. 38:55-94.

Tuccimei P, Salvati R, Capelli G, Delitala MC, Primavera P, 2005. Groundwater fluxes into submerged sinkhole area, Central Italy, using radon and water chemistry. Appl. Geochem. 20:1831-1847.

Tuttle MLW, Breit GN, Cozzarelli IM, 2009. Processes affecting $\delta^{34} \mathrm{~S}$ and $\delta^{18} \mathrm{O}$ values of dissolved sulfate in alluvium along the Canadian River, central Oklahoma, USA. Chem. Geol. 265:455-467.

Vannière B, Colombaroli D, Chapron E, Leroux A, Tinner W, Magny M, 2008. Climate versus human-driven fire regimes in Mediterranean landscapes: the Holocene record of Lago dell'Accesa (Tuscany, Italy). Quatern. Sci. Rev. 27:11811196.

Vaselli O, Tassi F, Montegrossi G, Capaccioni B, Giannini L, 2006. Sampling and analysis of volcanic gases. Acta Vulcanol. 18:65-76.

Waltham T, Bell F, Culshaw M, 2005. Sinkholes and subsidence. Springer: $382 \mathrm{pp}$.

Whiticar MJ, 1999. Carbon and hydrogen isotope systematic of bacterial formation and oxidation of methane. Chem. Geol. 161:291-314.

Williams P, 2003. Dolines, p. 304-310. In: J. Gunn (ed.), Encyclopedia of caves and karst science. Taylor and Francis Group.

Winfrey MR, Nelson DR, Klevickis SC, Zeikus JG, 1977. Association of hydrogen metabolism with methanogenesis in Lake Mendota sediments. Appl. Environ. Microbiol. 33:312318.

Woese CR, Kandler O, Wheelis ML, 1990. Towards to a natural system of organisms. Proposal for the domains Archaea, Bacteria and Eucaria. P. Natl. Acad. Sci. USA 87:4457644579.

Wüest A, Piepke G, Halfmann JD, 1996. Combined effects of dissolved solids and temperature on the density stratification of Lake Malawi (East Africa), 183-202. In: T.C. Johnson and E.O. Odada (eds.), The limnology, climatology and paleoclimatology of the East African lakes. Gordon and Breach.

Zhang J, Quay PD, Wilbur DO, 1995. Carbon isotope fractionation during gas-water exchange and dissolution of $\mathrm{CO}_{2}$. Geochim. Cosmochim. Acta 59:107-114. 